\title{
Peaceful Transitions and Democracy*
}

\author{
REŞAT BAYER \\ Department of International Relations, Koç University
}

While there has been extensive interest in the role of democracy in reducing interstate violence, the role of democracy in reaching higher levels of peace has received much less attention. Since many countries have less than amicable relations, it is necessary to consider how the quality of peace can be improved. The quality of peace becomes particularly relevant when assessing relations of countries with a bellicose past. In order to capture improvement in relations this article relies upon a framework that captures the various levels of peace that countries experience. The study maintains that democracy contributes to former belligerents reaching the highest levels of peace but that it is not helpful at the lower levels especially if only one side is a democracy. The article tests arguments on a data set that captures the transitions from one level of peace to another for all former belligerents since 1816 and relies upon event history analysis. The results for peace are not the opposite of what is found for war. The findings demonstrate that democracy plays a substantial role in peaceful transitions at all levels. However, while joint democracy is important for reaching the highest levels of peace, democracy can hamper the progress of relations at the lowest levels of peace.

I thank Scott Bennett, Faten Ghosn, Glenn Palmer, Galia Press-Barnathan, Gary Goertz, Paul Diehl, Michael Bernhard, Kyle Joyce, Arie Kacowicz, Errol Henderson, Benjamin Miller, Jim Klein, the anonymous reviewers, and the journal editors for their suggestions on earlier versions. The data set can be found at http://www.prio.no/jpr/datasets. Please direct correspondence to rbayer@ku.edu.tr. 


\section{Introduction}

Peace is widely conceptualized as the absence of violence. In much of the conflict studies literature, peace is said to occur when data sets such as the Militarized Interstate Dispute Data set or Uppsala Conflict Data Program do not report use of force for a particular set of countries. The rivalry literature criticizes this approach (Diehl \& Goertz, 2000) by demonstrating that the non-observance of a hostile event in a given time point does not reveal much about the quality of relations as the sides can continue perceiving each other as threats. Other scholars have defined 'the absence of turmoil, tension, conflict and war' as negative peace and argued that a positive peace would entail substantially more: 'a condition of good management, orderly resolution of conflict, harmony associated with mature relationships, gentleness, and love' (Boulding, 1978: 3; Galtung, 1985). Overall, several scholars assess the scholarship on peace unfavorably: 'What can international relations theory and research tell us about peace? The first thing to keep in mind is that there is not much scientific knowledge about interstate peace' (Vasquez, 1996: 274).

While there is much focus on whether interstate violence has occurred or not, 'the quality of peace between or among the states in question' (Ericson, 2000: 146) has received limited attention. The disparity in the quality of peace becomes particularly apparent when considering relations between former interstate belligerents. The level of peace attained by France and Germany is an exemplar of model relations. In fact, this dyad has reached a level where resorting to violence is not an option for the leadership of either side when trying to solve differences. This is not the case for many other dyads. While not at the brink of warfare, relations between Greece and Turkey fall short of this stage. Decades of special attention by the international community produced limited improvement between Israel and its neighbors. India and Pakistan are close to averaging one war per decade. Continuing problems between Eritrea and Ethiopia suggest that improving relations is just as hard in the 
post-Cold War era. The United States has vastly different relations today with three Asian countries that it fought in the twentieth century: Japan, North Korea, and Vietnam. These dyads demonstrate considerable disparity in relations and leads to the following question: What makes some adversaries reach higher levels of peace while others fall short?

This article contributes to our understanding of peace by examining transitions to higher levels of peace between former belligerents and focuses on the role of democracy. A levels of peace framework is necessary as the focus here is on improvement in relations. The lack of interstate violence reveals limited information about the dyad. Only examining uses of force can make relations appear worse than they truly are, as the events can be isolated and not affecting the threat calculus of decision-makers. More worryingly, the lack of such events might lead to complacency on the true state of relations. Multiple levels of peace have not been used in the quantitative conflict literature but it is common in the stable peace literature as will be discussed below.

Given the interest in democracy in academia and policy circles, the lack of attention paid to it in improving relations in the quantitative conflict literature is surprising. While there are many cases where at least one side is a democracy, the impact of democracy on reaching higher levels of peaceful coexistence and reconciliation, i.e., 'mutually conciliatory accommodation between former antagonists' (Long \& Brecke, 2003: 1), remains unclear. In fact, even the lack of war between democracies does not translate to good relations. Argentina's relations with United Kingdom serves as a cautionary note here as both sides were democratic soon after the war but it was clearly not possible to talk of 'positive peace'.

The discussion next turns to a discussion of the levels of peace. Subsequently, the article presents the expectations on how democracy at various levels affects the prospects of improvement. Both the impact of single and joint democracy dyads on the transition to higher levels of peace are considered. The article argues that democracy only leads to improved 
relations under certain conditions. Other variables also receive attention. The ensuing methodology section discusses duration analysis, operationalization of the levels and variables. The next to last section shares the empirical analyses and discussions of the findings. The results support much of the expectations as democracy only improves the chances of reaching highest levels of peace under some conditions. The findings also demonstrate that the factors that affect hostility reoccurrence are not the same as those that affect chances of improvement.

\section{Theoretical Framework: Levels of Peace}

A conceptualization of interstate peace has to consider the extent to which the issues of incompatibility such as territory create expectations of violence as well as the degree to which alternate means, such as institutionalized relations, besides violence exist that can address conflict between countries. The stable peace literature is particularly relevant as it focuses on attaining 'a situation in which the probability of war is so small that it does not really enter into the calculations of any of the people involved' (Boulding, 1978: 13). Thus, peace occurs at various intensities: A low level of peace between former belligerents is one where there is not much more than a halt to fighting, i.e., a frozen war, whereas a high level of peace encompasses institutionalization of relations and mutually beneficial interactions. In order to contribute to accumulation, the levels of peace here emerge from dimensions present in other frameworks: Acceptance, interaction, and resolution of issues of contention.

Acceptance or recognition of the other is an important milestone in relations.

Recognition by others is a central element in determining statehood. When two sides do not recognize each other's existence, this constitutes a fundamental challenge to the other and reconciliation is clearly not part of the picture. Thus, an important step is to demonstrate acceptance of the other. Yet, acceptance alongside minimum interaction between the two 
suggests problems. Deutsch et al. (1957: 201) pointed towards the importance of 'more and better communication'. Bar-Siman-Tov (2004: 67-68) highlights the role of comprehensive ties as 'the sides learn the value of peace relations, and deepen the trust between them'. Thus, it is also necessary to consider the amount of bilateral ties when assessing the state of relations. However, it is hard to envisage a dyad occupying a high level of peace when the underlying issues of the conflict remain. Thus, the protagonists need to cease seeing each other as threats and conflict resolution is necessary.

Based on these three dimensions, three levels of peace emerge: frozen peace, cold peace, and warm peace (see Goertz, 2006 for the use of adjectives). ${ }^{1}$ Frozen peace is a state of relations where the conflict is far from being resolved, coercion is seen as the primary means of dealing with conflict and there is a relatively high expectation of war. The sides do not appear to accept each other as equals and minor headway has been made in relations besides the war ending. There is almost no cooperative interaction and much villanization of the other (Spector, 1998). The interaction is limited to discussions between official channels and there is also likely to be considerable military postulations. Issues of contention remain. In such an atmosphere, the members of the two societies will see the other society as a threat. North Korea's relations with the United States are still in frozen peace fifty years after the Korean War cease-fire. Similarly, Israel throughout the Cold War years was at frozen peace with most of the Arab countries.

At cold peace, the sides recognize each other's right to existence but unresolved issues of contention are a central issue. Cold peace is a state where there is a step towards conflict resolution but the other side is still considered a threat to national security and expectations of war, while diminished, have not disappeared. Thus, while they accept the other, the situation

\footnotetext{
1 A level of peace framework is preferred here instead of a continuous approach to conflict and cooperation (Goldstein \& Freeman, 1990) as peace is not the same as cooperation. Klein, Goertz \& Diehl (2008) also raise the issue of weighing of events in the continuous approach as well as aspects of peace that are not specific events.
} 
is unsatisfactory from the point of conflict resolution. They might have some cooperative interactions, which might well be constrained due to ill will generated from the past.

However, even limited interaction between societies will result in more information about the other side and while information does not guarantee goodwill and trust, it can contribute to the better understanding of each other. The idea of major violent confrontation with the other side in the future still exists. It is quite possible that the existence of issues of contention next to some interactions results in bifurcated societies on how much the other side is a threat. This bifurcation will require leaders to tread carefully. Present-day Greece and Turkey are in cold peace, as are Egypt and Israel.

Warm peace is conceptualized as a state where the issues of rivalry have been resolved, expectations of war are non-existent and non-coercive techniques are prevalent. There is much cooperative interaction between them. Similarly, Kelman solving' (1999: 197) maintains that 'a positive peace in relationship between nations or communities with a long history of conflict has four essential components: mutual acceptance and reconciliation; a sense of security and dignity for each nation or community; a pattern of cooperative interaction between the nations or communities; and institutionalization of a dynamic process of problem. The sides are not expected to be in complete harmony and there can be issues of difference. Majority of society, including the elites, no longer sees the other side as a significant threat to national security and war is no longer an option. Current day France and Germany as well as Mexico and USA are in warm peace.

Existing frameworks (see Kacowicz \& Bar-Siman-Tov, 2000) have not been used in statistical analysis and many studies have not discussed how transitions will occur. There is considerable overlap with other frameworks. All of the frameworks focus on post-hostility relations with a very low state of peace that has no more than an end to war and a much higher state of peace that has institutionalized relations. For example, the levels of Miller 
(2001, 99-100) appear at first to be different as his focus is on regions but his 'cold war' (or 'diplomacy of violence') ‘cold peace,' (which falls 'short of complete reconciliation'), and 'warm peace' (where 'institutionalized nonviolent procedures to resolve conflicts are in place'), are reminiscent of the three levels. Similarly, the scale of Klein, Goertz \& Diehl (2008) for non-rivals ranges from a level with no recognition of the other to relations where there are institutionalized mechanisms to address conflicts. Rivalry plays an important role in the operationalization here. The framework presented here also makes it possible to capture the movements within rivalry as a pair of rivals can go from frozen peace to cold peace.

\section{Democracy and Peace}

Political competition and participation are central to democracy (Dahl, 1971). Elections serve as the main instrument through which these dimensions come about in practice as people have the right to vote and the right to run for office in fair, free and regular elections. Beyond elections, elements of civil society such as associations and social movements also indicate political interests. Thus, people have several mechanisms through which to hold rulers accountable in democracies. Accountability to some constituency is present in all regimes but when the constituency constitutes of citizens, a much more inclusive grouping, 'the exchanges of information, justification and judgment' become much more complex and demanding (Schmitter, 2004: 49; Bueno de Mesquita et al., 2003).

There is considerable evidence that democracies refrain from fighting each other (Bremer, 1992) and democracy was a central element in Immanuel Kant's (1795/1996) plan for perpetual peace. Since the focus here is on former belligerents, it is necessary to look at the findings for democracy in the protracted conflict literature. Protracted conflict or rivalry refers to a 'type of on-going and seemingly unresolvable conflict' where there are outbreaks of intensive armed hostility over time (Azar, 1986: 28). Diehl \& Goertz (2000) report that as 
the number of democracies in the dyad increases there is less probability of rivalry initiation and greater chance of termination. However, there is disagreement on whether it has any effect for recurrent conflict in general (Fortna, 2004; Senese \& Quackenbush, 2003). The impact of democracy also varies by the stage of the rivalry with Goertz, Jones \& Diehl (2005) finding that democracy increases the time between dispute in the early stages of the rivalry but not at an enduring rivalry. Thus, within the protracted conflict literature there is an expectation that democracy, particularly joint democracy, decreases violence but much remains unclear.

The stable peace literature is tied to the protracted conflict literature as it is interested in how former enemies improve their relations. Several scholars suggest that internal institutional similarity and compatible values contribute to attaining stable peace, particularly if the domestic systems are democratic (Deutsch et al., 1957; Adler \& Barnett, 1998; Ericson, 2000; Kacowicz \& Bar-Siman-Tov, 2000). Bar-Siman-Tov (2004: 67) argues that 'the presence of democracies is ... sufficient, although not necessary, for the emergence of stable peace' and Russett (1993: 42) maintains 'that to use or threaten to use force is not usually normatively acceptable behavior in disputes between democracies, even in the form of symbolic, ritualized bargaining behavior. Relations between democracies therefore fit into the category of "stable peace".

The reason for why this occurs is unclear but Russett (1993) argues that democracies act differently to fellow democracies due to shared domestic institutions and norms. Leaders of democracies have a set of expectations relating to the other side emerging from their own socialization on how democracies behave whereby they both expect the other to be similarly constrained domestically as well as to rely on compromise and negotiation in resolving conflict leading to an expectation of nonviolence (Ericson, 2000). This would suggest that if 
both sides are democratic, improvement in relations can come about as leaders can identify with each other on a number of points and an expectation of nonviolence would arise.

Thus, the literature expects democracy to improve relations especially if both sides are democratic. Yet, non-democracies might find it easier to make concessions and this could help to improve relations. For example, a leader in Turkey under democratic rule would have found it harder than Turkish President Kenan Evren, who had led the 1980 coup, to approve of Greece's readmission into NATO's military command structure. Moreover, much of the literature has not considered levels of peace (but see Ripsman, 2005). The different levels of peace might bring different elements within democracy to the forefront, which might not necessarily contribute to improved relations.

\section{Expectations on Democracy}

\section{Democracy at Frozen Peace}

Institutional checks restrain the hand of the leader in democracies when it comes to using force. However, there are other constraints as well. Given the lack of interaction among the societies and the bitter state of relations, the public is unlikely to have friendly feelings towards the other. A particularly important concern here is with constituents. Public opinion is not dovish and democracies have been found to act differently from what the democratic peace theory suggests when facing extreme conditions (Elman, 1997), which prevail in frozen peace. Leaders in democracies suffer greater domestic audiences when they appear to act contrary to past public declarations (Fearon, 1994) and electoral punishment can follow from appearing too conciliatory to the enemy (Colaresi, 2004). Azar (1986) argues that at the heart of most international conflict lies societal needs, such as security and identity, over which compromises are not possible. The public is likely to question the wisdom of cooperating with a side that had been presented as a primary threat previously and once an image has 
formed, there is a great resistance to updating it (Jervis, 1976). Given the rhetoric that the state apparatus used to legitimize the policies against the other side in the past, the leadership will want to avoid looking like it is appeasing the other side, which can be equivalent to political suicide. As accountability is particularly an issue in democracies, the constituents' demands for tough policies can reduce the options available to the leader compared to a nondemocracy.

Civil society mechanisms in democracies should make it easier for those who want tougher actions to organize themselves. Discarding political entities that see any conciliatory movement as unacceptable, i.e., 'spoilers,' is not feasible in this atmosphere. Thus, spoilers are likely to dominate public discourse and influence decision-making. Given the state of relations at frozen peace, even if the leaders of two democracies reach an agreement, it is unlikely that their constituents will accept it easily (Putnam, 1988). By appearing too conciliatory, just like with intrastate peace processes, 'leaders put themselves at risk from adversaries who may take advantage of a settlement, from disgruntled followers who see peace as a betrayal of key values, and from excluded parties who seek either to alter the process or to destroy it' (Stedman, 1997: 5). Democratic leaders can particularly 'be accused of being hypocritical; they turn the demons of last week into the legitimate and respectable partners of this week. At its worst, leaders ... can be accused of being appeasers and traitors' (Spector, 1998: 49). Thus, the leader can appear weak and create tensions with constituents by adopting conciliatory measures. In fact, for leaders in democracies needing to bolster their domestic standing, the presence of such an external threat can be a godsend and the public in democracies can nudge the government to take a confrontational stance (Elman, 1997).

The two sides might also not recognize each other as democracies (Owen, 1997). For example, Turkey's official view was that as Turkish Cypriots were not allowed to vote in elections in the Greek majority part of Cyprus, it could not be called a democracy. There is 
likely to be suspicion among the elites about the other side, particularly if the other side is not a democracy. There might be an expectation among the elites in a democracy that the other side is prone to acting irrationally and irresponsibly (Owen, 1997) based on their assessment of the other side's domestic structure leading to the conclusion that force will work more effectively. At the same time, the democracy in question might be an 'illiberal democracy' (Zakaria, 1997) where freedoms are limited and tolerance is lacking, e.g., Georgia and Russia. The limitation of freedoms might make it harder for the non-democracy to verify information (Schultz, 2001) and determine the extent to which the 'democracy' is bluffing. This can result in more violence. Thus, transparency, which is associated with contributing to the reduction of violence among democracies, might be missing. Yet, transparency, when it exists, might be problematic since the relative openness of the democratic system can result in considerable amount of information being disclosed that demonstrates the extent of its hostility to the other. At this level, joint democracy is likely to be a rare phenomenon, e.g., Argentina-UK, but there will be many instances where only one side is a democracy, e.g., China-USA for post-World War II era or North Korea and most of its Western adversaries. If there is a single democracy, the prognosis at frozen peace further worsens as the differences in regimes will make it easier to vilify the other. The different sort of institutions and norms will lead to considerable uncertainty and suspicion. The sides might not demonstrate much empathy towards the other's domestic constraints. Given that the sides are at frozen peace where there is extensive distrust already, the addition of pronounced difference in political regimes will make improvement truly daunting. The difference in regimes can make the other side appear more threatening to the constituents and result in spoilers finding it easier to recruit people. As such, democracy is unlikely to improve relations when relations are at frozen peace. Thus, we expect single democracy dyads at frozen peace to decrease chances of reaching cold peace. 


\section{Democracy at Cold Peace}

As societies do not see each other as clear threats and villains in cold peace, the situation will be considerably different for decision-makers of democracies. Thus, the traditional explanations associated with democracy should contribute to improved relations, as there is not a garrison state mentality at this level. In an atmosphere where the extreme fear concerns of frozen peace have disappeared, leaders of two democracies can expect each other to have similar norms relating to negotiation and nonviolence when it comes to conflict, i.e., complete physical annihilation of the opponent will be off the menu. If both sides are democratic, the similar domestic institutions will make it easier to understand each other's decision-making process, which should further reduce uncertainty. Both sides will know that the other side is also constrained and that it is accountable domestically. The additional information and transparency that democracies supply will help to better understand the needs of the two sides and contribute to attaining warm peace. Examples of joint democracies include AustraliaJapan as well as Argentina-Brazil in recent times.

While elites can see international issues as 'mere opportunities for scoring points with their own domestic constituencies' (Azar, 1986: 33), there will be less temptation for leaders to try to rally the flag against the other as the public is less likely to be interested given that they are not at frozen peace. There will still be significant differences but leaders will estimate that the other side cannot easily engage in adventures given the potential of domestic reprisal. Importantly, leaders will face less charges of hypocrisy by the constituents when they make overtures. Overall, the other side also being a democracy should lead to less fears of survival and the expectations of the literature on the role of joint democracy should materialize.

While there will still be those who are against the process, these groups will find that they do not control the public discussion. Other elements within society who prefer moderation or improved relations can become more vocal. One advantage of both sides being 
democratic will be that the relative openness will allow each leader to see the level of support for improved relations in both societies resulting in more effective conflict management (Dixon, 1993). At the same time, given that democracies tend to cooperate more with each other on a number of fronts, including trade (Morrow, Siverson \& Tabares, 1996), this should translate to constituents who would like relations to improve, as this will reduce the uncertainty in transactions. As constituents tend to follow the flag (Pollins, 1989), it is only at cold peace where there is room for interaction that a sizeable pro-cooperation constituency emerges.

The above discussion also applies if there is only one democracy in the dyad, e.g., Mexico-USA for much of twentieth century and China-Japan, but with limitations. In addition to there not being the benefits of the leaders knowing that the other is similarly constrained and operating with similar norms, the domestic audience is likely to be wary about the other side resulting in the leaders being cautious about pushing the constituents. For the spoilers, this should again make it easier to recruit people to their side. While the increased societal interactions are likely to create groups that want even better relations, it is unlikely that they will be as big as they would have been if both sides were democratic. Thus, the dynamics of the inter-democratic relations will be missing but there are several reasons why even a single democracy might contribute. Given the relative openness of the democratic structure, this will make it easier for the non-democracy to verify some of the information and boundaries presented by the democracy, particularly regarding the constituents (Schultz, 2001). The benefits from rallying the flag against the other side will again be limited. As the sides are no longer at frozen peace where there is likely to be much more attention, the negotiators will find that they are less constrained domestically. This situation can contribute to building trust, resulting in the share of more information about their interests, and 
potentially make it easier to improve the relations. Thus, we expect joint democracy dyads at cold peace to increase chances of reaching warm peace.

\section{Control Factors}

The effects of present-day determinants such as interest similarity, power changes and recent conflict are first considered for transitions from frozen peace to cold peace and cold peace to warm peace. Foreign policy interest similarity reveals the interconnectedness of the actors to each other. However, interest overlap can be seen as of a temporary nature and thus at frozen peace given the state of relations it is expected to be inconsequential. At cold peace, similarity would remind them of their importance to each other and contribute to improved relations. Relative power changes can affect the dynamics within the dyad. It is certainly possible to envisage a change in relations if one of the sides started to enhance its position vis-à-vis the other. However, such changes are not expected to be consequential at either level. Leaders might find it hard to communicate credibly to the other side that its capability has increased (especially at frozen peace) or that this is a permanent change (Blainey, 1988). They also run the risk of threatening other countries. The 'past-crisis as a catalyst' argument (Lebow, 1981; Rock, 1989) suggests that more violent, recent episodes of conflict can affect the decisionmaking. These recent crises act as shocks and give additional impetus to improve relations. This is expected to make a difference in particular at cold peace as sides have more to lose due to increasing interactions and the crisis would remind the sides of the costs of conflict.

Many states have more than one country with which they have tense relations and leaders can consider improving relations with the lesser of two threats instead of facing several countries at the same time. Diplomatic history is replete with such third parties playing a crucial role when it comes to improved relations and even formation of a common identity (Orme, 2004; Owen, 2000). The logic of 'enemy of my enemy is my friend' 
suggests that if one country faces the increasing threat, the other can potentially try to use the other's additional security problems to its advantage, and thus, at frozen peace, this should make it harder to improve relations. However, at cold peace, the presence of this threat can make it easier for the leader to overcome spoilers by demonstrating that there are more pressing security concerns.

While the political outcome of the last war can create bitterness and induce a desire to alter the status quo, it is expected here that such settlements will result in transitions to cold peace and warm peace. Existing literature (Senese \& Quackenbush, 2003; Maoz, 1984) demonstrates that imposed settlements increase the time between disputes as they reduce uncertainty as to who emerged stronger from the war (Blainey, 1988). Finally, countries that are geographically distant from each other are unlikely to place improving relations with the other side at the top of their agenda, as they are likely to have more pressing issues. Thus, as the distance increases, the chances of a transition from either frozen peace or cold peace should decrease. $^{2}$

\section{Research Design}

\section{Cases}

All pairs of states previously in an interstate war between 1816 and 1992 are included. War is the starting point here as it is a major global event that is likely to have an impact (Jervis, 1976). It is standard to study political actors after interstate violence in stable peace literature as studying all states would include countries with little need to improve relations. The unit of analysis is former belligerent dyad-year. Each pair of former belligerents has one line of data containing information for each year that they are in the sample from the end date of their first war onwards, i.e., a non-directed dyad setup. There are 259 pairs of states in the data set.

\footnotetext{
2 Trade was considered (Press-Barnathan, 2006) but it was excluded as there would have been considerable reduction in sample size.
} 
Information on interstate wars was obtained from Correlates of War (COW) scholars (Small \& Singer, 1982; Jones, Bremer \& Singer, 1996; Stam, 1996; Maoz, 1999; Sarkees, 2000;

Ghosn, Palmer \& Bremer, 2004) as well as others (Clodfelter, 2002). Following COW guidelines, a participant in an interstate war is a member of the interstate system and either suffered 100 military casualties or at least had 1,000 military personnel engaged in combat in a violent sustained conflict where there were 1,000 battle fatalities among all state participants. Once a dyad enters the data set following their first war after 1816 , it is under examination until one of the states no longer exists, or until 1992, the last year of available data.

\section{Levels of Peace}

Multiple components are relied upon in order to differentiate the three levels of peace as can been seen in Table I. These include the presence of diplomatic relations, the type and number of agreements, and the termination of rivalry between them in order to capture respectively whether the two sides recognized each other as equals, the amount of bilateral interaction, and resolution of issues of contention. While other studies have also suggested similar components (Klein, Goertz \& Diehl, 2008), this study is the first that we are aware of which relies on these components to create a level of peace data set for all former belligerents.

\section{(Table I)}

For a pair of states to be in frozen peace, they must not be recognizing each other. A dyad is in frozen peace if either diplomatic ties (Singer \& Small, 1973) or peace treaties (Werner, 1999) are missing. Fulfilling either of these criteria would move it to cold peace. Thus, North Korea and USA are in frozen peace for the entire span of this study. Israel is in frozen peace with its Arab adversaries in the span of this study, except Egypt. This is the 'lowest' level of peace where the dyad has not done more than to end the war and reconciliation has 
not started (Ackermann, 1994). In this and subsequent levels, a dyad can exit the level by going back to war, by not fulfilling the requirements of the level, right-censoring due to data running out in 1992 or an earlier year if the dyad does not last until that point, or by moving to a higher level (except at warm peace). Right-censoring occurs here as the full history of the cases is not observed (in this case the history beyond 1992) even though the observations are still at risk of exiting from the level.

The ending of frozen peace through establishment of diplomatic ties and/or signing of a peace treaty indicates that the dyad is in cold peace. The presence of these factors indicates that the sides recognize each other's right to existence. The peace treaty generally comes first, e.g., Egypt and Israel enter this level in 1979 following their peace treaty. However, diplomatic ties can recommence before the signing of a peace treaty. In addition, peace treaties were relied upon less during the Cold War and this suggests that this instrument might have fallen out of fashion. As such, it is necessary to consider both elements in this study. In addition, a dyad in cold peace either has a substantive issue that awaits resolution or insufficient interactions.

For a dyad in warm peace, the sides need to recognize each other, resolve all outstanding problems, and undergo sufficient amount of interaction. The sides recognize each other by maintaining diplomatic relations and demonstrating that the war is over by signing a major treaty, which is generally a peace treaty, but for some dyads, other sorts of agreements such as security or cooperation agreements have historically achieved the same feat. The sides also need to have signed 10 different formal bilateral agreements with each other (Rohn, 1983; Parry, 1969-1983). Agreements help to capture cooperative interactions and the extent to which relations are contractualized. The non-implementation of agreements might be an issue at cold peace but that is also the reason for requiring many agreements here as the sheer amount indicates that the sides believe that such agreements are useful and suggests that 
options other than violence are seen as useful in solving problems. In order to make sure that the agreements were not limited purely to one issue area and that relations were moving beyond a military one, the agreements are further required to capture a broad range of topics (Bar-Siman-Tov, 2004) such as military, economic, environmental, societal and political areas. In addition, the sides need to indicate that they have resolved their main issues of contention and ended their rivalry. The strategic rivalry list of Thompson (2001) focuses on the perceptions of the leaders and issues of contention through an examination of diplomatic history. Since it attempts to capture mutual enemy perception, it was particularly appropriate here. In order to make sure that the higher level of peace is not the same as the end date of a rivalry, in cases where the sides had issues of contention, they need to have five additional agreements from the end date of the rivalry.

There are 2,234 cases of frozen peace with 254 transitions to cold peace. Frozen peace mostly follows the end of the war with only $10 \%$ of the cases going from the end of war directly into cold peace. It needs to be borne in mind that while some pairs of countries experience several transitions to cold peace from frozen peace, others do not experience it at all. For example, China and USA due to their several wars have several transitions from frozen peace. There are 22 wars at frozen peace. Downturn in relations for reasons other than wars are also capture, i.e., Iran and UK's relations deteriorate to frozen peace after the political upheaval in Iran. There are 5,675 cases of cold peace with 130 transitions to warm peace. There are fewer transitions to warm peace than to cold peace and this lends additional support to the validity of the measures, as more transitions from cold peace to warm peace would have been problematic given that it is hard for states to reach such a high level. There are 48 wars at cold peace.

\section{Statistical Estimation Technique}


The interest here is in capturing the role that democracy plays in the transition from a lower level of peace to a higher level. Each of the levels of peace can be considered here as conditions or states. The amount of time that a pair of countries can spend at a given condition varies. Ordinary least squares and logistic regression techniques as well as path analysis are not ideal for factoring in time or addressing the problem of right-censoring. Since there are a series of transitions and we are also interested in factoring in time, selection models would not be appropriate. Event history analysis is relied upon here because such models provide answers to both whether a change is registered as well as when it took place (Beck, Katz \& Tucker, 1998; Box-Steffensmeier \& Jones, 2004). The statistical estimations in the ensuing models rely upon duration analysis, which is standard in the protracted conflict literature. Duration analysis studies the time it takes to reach any of the possible types of events and the coefficients in such models can be discussed in terms of risk. Unlike other techniques, duration analysis explicitly takes into consideration the amount of time spent in some condition. A key feature of such analysis is the hazard rate, which gives the instantaneous rate at which events end at a certain time given that they had managed to survive until that time. A positive coefficient indicates that the hazard is increasing so that the duration until the event occurs shortens and a negative one implies that the hazard is decreasing and that the duration until the event occurs lengthens. Cox regression (Cox, 1975) is used because it makes few assumptions about the shape of the hazard function and avoids forcing an incorrect distribution on the model. The Cox model can be expressed as $\mathrm{H}_{\mathrm{i}}(\mathrm{t})=\mathrm{h}_{0}(\mathrm{t}) \exp \left(\beta^{\prime} \mathrm{x}\right)$ where $\mathrm{h}_{0}(\mathrm{t})$ represents the baseline hazard function and the rest of the function captures the covariates and parameters. Since there are multiple levels, a Cox model from time of previous event is used (Cleves, 1999; Box-Steffensmeier \& Jones, 2004), and not from time of first entry into the data set, as it is necessary for the time to be reset after an event takes place. In addition, for pairs of states where one or both exit the COW 
international system for a number of years, e.g., Japan after World War II, analysis begins only after they are both members of the system.

The constant proportional effects assumption, i.e., the effects remaining constant over time, is important in Cox models. Following Box-Steffensmeier \& Jones (2004), the offending covariate and an interaction term with $\log$ of time of the offending covariate were included in order to allow for nonproportionality in their effects. Interpretation of these coefficients is no different from that of other interaction coefficients.

The protracted conflict literature demonstrates that some pairs of states account for much of the violence, including war, and, thus, it is necessary to consider war onset as one of the ways through which former belligerents exit their level. This study relies upon a competing risk framework (Box-Steffensmeier \& Jones, 2004) where each former belligerent year is at risk of experiencing a transition to higher level of peace or experiencing another war with the same adversary. We specify two separate models for each level. This allows covariates to have different effects across the two outcomes and allows us to compare how the factors affect the chances of war as well as attaining higher levels of peace.

\section{Independent Variables}

The first three variables are binary. 'Joint Democracy' captures whether both countries have scores greater than 6 in the combined autocracy-democracy -10 to +10 scale of Polity (Marshall \& Jaggers, 2002). 'Single Democracy' is coded as 1 if only one side has a score greater than 6 in the scale. 'Imposed Settlement' captures whether the war was concluded with an imposed settlement according to MID data set, which defines an imposed settlement as 'an agreement that has been forced on another state by means of overwhelming authority and without invitation' (Jones, Bremer \& Singer, 1996: 181). The rest of the variables are continuous. 'Foreign policy Similarity' is the weighted global ' $S$ ' score for the dyadic 
alliance portfolio between 1816 and 1945 and after 1945 the average of the alliance portfolio score and the UN voting similarity score (Signorino \& Ritter, 1999: 136; Gartzke \& Jo, 2002). 'Change in Relative Power' is the difference in the annual growth rates in each year of observation in the dyad: (((Pi,t - Pi,t-1)/Pi,t-1) - ((Pj,t - Pj,t-1)/Pj,t-1)) where 'P' depicts power of either of the two subscripted states (' $i$ ' or ' $j$ ') at time ' $t$ ' or ' $t-1$ ' (Werner, 1999; Singer, Bremer \& Stuckey, 1972; Bennett \& Stam, 2000). 'Recent conflict' is based on conflict component of Crescenzi \& Enterline's (2001) International Interaction Score where the value is lagged one year and bounded. 'Third Party Conflict' relies on the same component and sums the level of animosity that the two sides are experiencing with other countries. 'Distance' is measured between capitals (and ports in the case of Russia and USA) (Small \& Singer, 1982).

\section{Results}

The findings for transition from frozen peace and cold peace to a higher level of peace and war are shared in Table II. In the models estimated here there are 46 instances of joint democracy in frozen peace and 446 instances of joint democracy in cold peace as well as 1,316 instances of a single side being a democracy in frozen peace and 2,423 instances in cold peace. While joint democracy is rare in frozen peace, clearly this is not the case for single democracy dyads.

\section{(Table II)}

The presence of having joint democracy does not affect the chances of moving to cold peace from frozen peace. On the other hand, the results demonstrate that joint democracy statistically significantly increases the chances of reaching warm peace from cold peace. Given that stable peace scholars have argued that both sides need to be democracies, this 
finding further supports their contentions. Jointly democratic dyads are $7.86[=\exp (2.063)]$ times more likely to make the transition from cold peace to warm peace.

The presence of a single democracy results in a $26 \%$ decrease in chances of a transition from frozen peace to cold peace. The presence of a single democracy has a positive statistically significant effect when it comes to transition from cold peace to warm peace and they are 2.34 times more likely to make a transition from cold peace to warm peace. The impact of joint democracy ( $687 \%$ increase in the hazard) on improving relations at cold peace is greater than that of only one democracy as expected (134\%). Imposed settlement (812\%) increases the chances of a transition from cold peace by more than joint democracy but the effect wanes.

Thus, the results demonstrate that democracy's impact on peace varies. There is no indication that the presence of democracy results in improvement of relations at frozen peace. This is understandable as the costs of undertaking measures to improve relations can be too high for most leaders to undertake. However, the results show that democracy increases the chances of moving to warm peace from cold peace. Thus, the expectations in the literature are qualified as the findings suggest that democracy helps to improve relations only when relations progress beyond a certain point. Specifically, only after relations reach a certain level does the presence of democracy make it easier for the sides to interact and work towards solving their problems.

The control variables capture several of the central areas of discussion in international conflict and cooperation literature. In none of the models is there any evidence that imposed settlement induces revenge. Likewise, Long \& Brecke (2003: 119) demonstrate that emotional traits play a limited role in interstate reconciliation. This suggests that former belligerents appear to be willing to accept the legitimacy of the new status quo. The results here indicate that imposed settlements prevent stagnation. 
Higher degrees of interest similarity result in an increase in the prospects of making a transition to cold peace over time. The results also indicate that increasing degrees of similarity raises the prospects of a transition to warm peace from cold peace but this effect wanes over time. What this suggests is that as time progresses the continued presence of high degrees of interest similarity loses its impact. Thus, if decision-makers do not take action quickly and build around the interests, then greater cooperation in other areas might not surface at cold peace.

While conflict with third parties initially decreases chances of moving to cold peace from frozen peace, sustained levels of high conflict with a third party start to worry leaders even at frozen peace and might lead to a policy adjustment. The results demonstrate that conflicts with third parties increase prospects of attaining warm peace from cold peace. The results underscore the importance of considering the context as increasing levels of external threats (Bennett, 1996) certainly contribute to peace but only within certain levels.

Recent conflict does not alter the chances of reaching cold peace from frozen peace. Somewhat surprisingly recent conflict decreases the prospects of improvement at cold peace at first but over time, this variable has a positive effect, which indicates that leaders take measures to reduce the potential of even costlier conflict in the future by improving their relations. Thus, the catalyst argument receives some support here but with qualifications as the potential of future losses alongside time contributes to improvement.

Change in relative power does not make a difference in attaining cold peace or warm peace. The signs are different under the two levels of peace suggesting different sort of dynamics but the variable remains insignificant. These results dovetail well with Werner's (1999) finding that power changes increase the rate of dispute occurrence as the findings here demonstrate that power changes do not lead to improved relations. Finally, countries that are 
further apart are less likely to improve their relations after war. This was expected as there will not be much urgency and relations will stagnate.

We also examined the transition to war at each of these levels. The results are shown in Table II and they will not be discussed in depth as the focus here is on transitions to higher levels of peace. War onset is rare in both levels as expected. There are no instances of joint democracies fighting a war and so this variable is omitted. The findings support the arguments here as single democracy increases the risk of war at frozen peace and decreases it at cold peace. Furthermore, the results are not just the mirror opposites of what is found for transitions to higher levels of peace. For example, recent conflict decreases risk of war at frozen peace and change in relative power increases risk of war at both levels. Imposed settlement has no effect. These and other findings demonstrate that the process for transitions to higher peace and war differ substantially.

We conducted additional estimations. The findings for democracy did not change when there were fewer control variables. The correlation between the variables does not surpass 0.5 . The correlations between the variable and its interaction with time are higher but it was necessary to include them for statistical reasons. In order to determine whether including both democracy variables was affecting the results, we ran models where only one of the two variables was included and found no major differences. We also examined whether any regime similarity would have the same effect to what was found for joint democracy. Variables for autocracy did not have a statistically significant effect. Finally, we assessed whether changes in domestic political systems rather than type of regime mattered as duration might make it easier for the two sides to understand each other's domestic constraints and reduce uncertainty. Regime duration did not reach statistical significance in any model and the democracy variables were not affected. 


\section{Conclusion}

The daily barrage of news on violence from around the world leads to the view that some international entities will always remain enemies. This study shows that this is not the case. More work on levels of peace is clearly needed, including between communal groups (Azar, 1986), but there is considerable room for optimism regarding prospects of reconciliation.

While many dyads find it hard to overcome their key differences, several dyads have moved to a point in their relations that was largely inconceivable at the turn of the last century and this article provided a first attempt at understanding this process.

The benefits of democratic rule are multifold. The findings lend statistical support for the first time to the argument that democracy contributes to the attainment of the highest levels of peace. At the same time, democracy does not always improve relations and might even impede the progress of relations. This could be because leaders in democratic societies find it harder to leave jobs half-finished given that they expect their constituencies to hold them accountable for changes in policy after having convinced the public that the other side was particularly threatening. Obviously, such an atmosphere is not particularly conducive for leaders to attempt to improve relations. Depending on the state of relations, dyads in which there is only one democracy require particular attention from the international community. In this regard, the results give support to arguments presented here and suggest that more work on domestic regimes and peace is required, including studies of how the level of peace affects democracy.

The results demonstrate that the role of factors is conditioned by the context that they are operating within. While some factors improve relations at one level, this is not the case at another level and thus factoring in the level of peace occupied by the protagonists is necessary. Factors such as power that have been shown to affect dispute recurrence did not play a role in improving relations and this further underlines the need to not only focus on 
violence when assessing relations. Conflict with others consistently affected the dyad members but had different consequences at the two levels. It is also necessary to examine more the complexities of settlements as well as how interest similarity arises.

This research did not consider conflict management techniques. Given that the international community is increasingly relying upon techniques such as mediation with varying levels of success, studying these techniques in relation to former belligerents is needed. Specifically, studying various conflict management techniques at the different levels can have practical policy implications and lead to potentially more effective third party participation. 
Table I. Conceptualization and Operationalization of Levels of Peace

\begin{tabular}{|c|c|c|c|}
\hline Conceptualization & Frozen Peace & Cold Peace & Warm Peace \\
\hline Accept Other & No & Yes & Yes \\
\hline Interact with Other & Negligible & Varies & Yes \\
\hline Resolved Differences & No & Varies & Yes \\
\hline Operationalization & Frozen Peace & Cold Peace & Warm Peace \\
\hline Diplomatic Relations & -- & Suffices & Necessary \\
\hline Peace Treaty & -- & Suffices & Necessary \\
\hline End of Rivalry & -- & -- & Necessary \\
\hline $\begin{array}{l}\text { Bilateral Agreements after } \\
\text { War (or after rivalry) }\end{array}$ & -- & -- & Necessary \\
\hline
\end{tabular}




\begin{tabular}{|c|c|c|c|c|}
\hline & \multicolumn{2}{|c|}{ Frozen Peace to } & \multicolumn{2}{|c|}{ Cold Peace to } \\
\hline & Cold Peace & War & Warm Peace & War \\
\hline Single Democracy & $\begin{array}{c}-0.305+ \\
{[0.179]}\end{array}$ & $\begin{array}{l}0.850+ \\
{[0.503]}\end{array}$ & $\begin{array}{c}0.851 * * \\
{[0.262]}\end{array}$ & $\begin{array}{l}-1.014 * \\
{[0.486]}\end{array}$ \\
\hline Joint Democracy & $\begin{array}{c}0.427 \\
{[0.489]}\end{array}$ & & $\begin{array}{c}2.063 * * \\
{[0.260]}\end{array}$ & \\
\hline Imposed Settlement & $\begin{array}{l}0.373+ \\
{[0.224]}\end{array}$ & $\begin{array}{c}0.434 \\
{[0.441]}\end{array}$ & $\begin{array}{l}2.211^{*} \\
{[0.910]}\end{array}$ & $\begin{array}{c}0.204 \\
{[0.438]}\end{array}$ \\
\hline Foreign Policy Similarity & $\begin{array}{c}0.194 \\
{[0.250]}\end{array}$ & $\begin{array}{l}-1.025 \\
{[0.688]}\end{array}$ & $\begin{array}{l}3.017 * \\
{[1.194]}\end{array}$ & $\begin{array}{l}-0.928 * \\
{[0.435]}\end{array}$ \\
\hline Change in Relative Power & $\begin{array}{c}0.083 \\
{[0.071]}\end{array}$ & $\begin{array}{l}-1.333 \\
{[0.820]}\end{array}$ & $\begin{array}{c}-0.453 \\
{[0.566]}\end{array}$ & $\begin{array}{l}1.126^{* *} \\
{[0.210]}\end{array}$ \\
\hline Recent Conflict & $\begin{array}{c}0.062 \\
{[0.219]}\end{array}$ & $\begin{array}{l}-1.582 * \\
{[0.686]}\end{array}$ & $\begin{array}{c}-2.396+ \\
{[1.231]}\end{array}$ & $\begin{array}{c}-5.761 * * \\
{[1.597]}\end{array}$ \\
\hline Third Party Conflict & $\begin{array}{c}-0.092 * * \\
{[0.024]}\end{array}$ & $\begin{array}{c}-0.141+ \\
{[0.085]}\end{array}$ & $\begin{array}{c}0.090^{* *} \\
{[0.031]}\end{array}$ & $\begin{array}{l}-0.162 * \\
{[0.076]}\end{array}$ \\
\hline Distance & $\begin{array}{c}-0.0001 * \\
{[0.00002]}\end{array}$ & $\begin{array}{c}0.00009 \\
{[0.0001]}\end{array}$ & $\begin{array}{l}-0.0001 * * \\
{[0.00003]}\end{array}$ & $\begin{array}{c}-0.0001 \\
{[0.00007]}\end{array}$ \\
\hline Imposed Settlement $*$ Time & $\begin{array}{c}0.466 * * \\
{[0.167]}\end{array}$ & & $\begin{array}{c}-0.489+ \\
{[0.292]}\end{array}$ & \\
\hline Foreign Policy Similarity * Time & $\begin{array}{c}0.515^{* *} \\
{[0.190]}\end{array}$ & $\begin{array}{l}1.480^{*} \\
{[0.660]}\end{array}$ & $\begin{array}{l}-0.931^{*} \\
{[0.398]}\end{array}$ & \\
\hline Change in Relative Power * Time & & $\begin{array}{l}1.532 * * \\
{[0.494]}\end{array}$ & $\begin{array}{c}-0.359 \\
{[0.383]}\end{array}$ & \\
\hline Recent Conflict $*$ Time & & & $\begin{array}{l}1.335^{* *} \\
{[0.465]}\end{array}$ & $\begin{array}{l}1.505^{* *} \\
{[0.512]}\end{array}$ \\
\hline Third Party Conflict $*$ Time & $\begin{array}{c}0.109 * * \\
{[0.024]}\end{array}$ & $\begin{array}{c}0.095 \\
{[0.068]}\end{array}$ & & $\begin{array}{c}0.085^{* *} \\
{[0.032]}\end{array}$ \\
\hline Distance * Time & $\begin{array}{c}0.00005+ \\
{[0.00002]}\end{array}$ & $\begin{array}{c}-0.0004 * \\
{[0.0001]}\end{array}$ & & \\
\hline Observations & 2116 & 2116 & 5618 & 5618 \\
\hline Wald Chi(2) & 115.13 & 80.95 & 140.3 & 107.21 \\
\hline Log Likelihood & -905.6 & -84.83 & -424.43 & -173.89 \\
\hline Robust standard errors in brackets & + significant at & $\%$; * sign & $5 \% ; * *$ signi & ant at $1 \%$ \\
\hline
\end{tabular}




\section{References}

Ackermann, Alice, 1994. 'Reconciliation as a Peace-Building Process in a Post-War Europe: The Franco-German Case', Peace and Change 19(3): 229-250.

Adler, Emanuel \& Michael Barnett, eds, 1998. Security Communities. Cambridge: Cambridge University Press.

Azar, Edward, 1986, 'Protracted International Conflicts: Ten Propositions,' in Edward Azar \& John Burton, eds, International Conflict Resolution: Theory and Practice. London: Wheatsheaf (28-39).

Bar-Siman-Tov, Yaacov, 2004. 'Dialectics between Stable Peace and Reconciliation', in Yaacov Bar-Siman-Tov, ed., From Conflict Resolution to Reconciliation. New York: Oxford University Press (61-80).

Beck, Nathaniel; Jonathan Katz \& Richard Tucker. 1998. 'Taking Time Seriously: Time Series-Cross-Section Analysis with a Binary Dependent Variable', American Journal of Political Science 42(4):1260-1288.

Bennett, Scott, 1996. 'Security, Bargaining, and the End of Interstate Rivalry', International Studies Quarterly 40(2): 157-183.

Bennett, Scott \& Allan Stam, 2000. 'EUGene: A Conceptual Manual', International Interactions 26(2): 179-204. Data accessed through http://eugenesoftware.org. Blainey, Geoffrey, 1988. The Causes of War. Third Edition. New York: Free Press. Boulding, Kenneth, 1978. Stable Peace. Austin, TX: University of Texas Press.

Box-Steffensmseier, Janet \& Bradford Jones, 2004. Timing and Political Change: Event History Modeling in Political Science. Cambridge: Cambridge University Press.

Bremer, Stuart, 1992. 'Dangerous Dyads: Conditions Affecting the Likelihood of Interstate War, 1816-1965', Journal of Conflict Resolution 36(2): 309-341. 
Bueno de Mesquita, Bruce; Alastair Smith, Randolph Siverson \& James Morrow, 2003. The Logic of Political Survival. Cambridge, MA: The MIT Press.

Cleves, Mario, 1999. 'Analysis of multiple failure-time data with Stata', Stata Technical Bulletin 9: 38-49.

Clodfelter, Michael, 2002. Warfare and Armed Conflicts: A Statistical Reference to Casualty and Other Figures, 1500-2000. Jefferson, NC: McFarland.

Colaresi, Michael, 2004. 'When Doves Cry: Unreciprocated Cooperation and Leadership Tenure', American Journal of Political Science 48(3): 555-570.

Cox, David, 1975. 'Partial Likelihoods', Biometrika 62(2): 269-276.

Crescenzi, Mark \& Andrew Enterline, 2001. 'Time Remembered: A Dynamic Model of Interstate Interaction', International Studies Quarterly 45(3): 409-43.

Dahl, Robert, 1971. Polyarchy: Participation and Opposition. New Haven, CT: Yale University Press.

Deutsch, Karl; Sidney Burrell, Robert Kann, Maurice Lee, Jr., Martin Lichterman, Raymond Lindgren, Francis Loewenheim \& Richard Van Wagenen, 1957. Political Community and the North Atlantic Area: International Organization in the Light of Historical Experience. Princeton, NJ: Princeton University Press.

Diehl, Paul \& Gary Goertz, 2000. War and Peace in International Rivalry. Ann Arbor, MI: University of Michigan Press.

Dixon, William, 1993. 'Democracy and the management of international conflict', Journal of Conflict Resolution 37(1): 42-68.

Elman, Miriam Fendius, ed., 1997. Paths to Peace: Is Democracy the Answer. Cambridge: MA: The MIT Press.

Ericson, Magnus, 2000. 'Birds of a Feather? On the Intersections of Stable Peace and 
Democratic Peace Research Programs', in Arie Kacowicz; Yaacov Bar-Siman-Tov,

Ole Elgstrom \& Magnus Jerneck, eds, Stable Peace among Nations. Lanham, MD: Rowman and Littlefield (130-139).

Fearon, James, 1994. 'Domestic Political Audiences and Escalation of International Disputes', American Political Science Review 88(3): 577-592.

Fortna, Page, 2004. Peace Time: Cease-Fire Agreements and the Durability of Peace. Princeton, NJ: Princeton University Press.

Galtung, Johan, 1985. 'Twenty-Five Years of Peace Research: Ten Challenges and Some Reponses', Journal of Peace Research 22(2): 141-158.

Gartzke, Erik \& Dong-Joon Jo, 2002. 'The Affinity of Nations Index, 1946-1996', Version 3.0. Data accessed through http://www.columbia.edu/ eg589/datasets.html. Ghosn, Faten; Glenn Palmer \& Stuart Bremer, 2004. 'The MID 3 Data Set, 1993-2001: Procedures, Coding Rules, and Description', Conflict Management and Peace Science 21(2): 133-154.

Goertz, Gary, 2006. Social Science Concepts: A User's Guide. Princeton, NJ: Princeton University Press.

Goertz, Gary; Bradford Jones \& Paul Diehl, 2005. 'Maintenance Processes in International Rivalries', Journal of Conflict Resolution 49(5): 742-769.

Goldstein, Joshua \& John Freeman, 1990. Three-Way Street. Chicago, IL: University of Chicago Press.

Jervis, Robert, 1976. Perception and Misperception in International Politics. Princeton, NJ: Princeton University Press.

Jones, Daniel; Stuart Bremer \& David Singer, 1996. 'Militarized Interstate Disputes, 1816-1992: Rational, Coding Rules, and Empirical Patterns', Conflict Management and Peace Science 15(2): 163-212. 
Kacowicz, Arie \& Yaacov Bar-Siman-Tov, 2000. 'Stable Peace: A

Conceptual Framework', in Arie Kacowicz; Yaacov Bar-Siman-Tov, Ole Elgstrom \& Magnus Jerneck, eds, Stable Peace among Nations. Lanham, MD: Rowman and Littlefield (11-35).

Kant, Immanuel, 1795/1996. 'Towards perpetual peace', in Mary Gregor, ed., Practical Philosophy. Cambridge: Cambridge University Press (317-351).

Kelman, Herbert, 1999. 'Transforming the Relationship between Former Enemies: A Social-Psychological Analysis', in Robert Rothstein, ed., After the Peace: Resistance and Reconciliation. Boulder, CO: Lynne Rienner (193-205).

Klein, James P.; Gary Goertz \& Paul Diehl, 2008. 'The Peace Scale: Conceptualizing and Operationalizing Non-Rivalry and Peace', Conflict Management and Peace Science 25(1): 67-80.

Lebow, Richard, 1981. Between Peace and War: The Nature of International Crisis. Baltimore, MD: John Hopkins University Press.

Long, William \& Peter Brecke, 2003. War and Reconciliation: Reason and Emotion in Conflict Resolution. Cambridge, MA: MIT Press.

Maoz, Zeev, 1984. 'Peace by Empire? Conflict Outcomes and International Stability, 1816-1976', Journal of Peace Research 21(3): 227-241.

Maoz, Zeev, 1999. 'Dyadic Militarized Interstate Disputes (DYMID1.0)', Available at Data accessed through http://spirit.tau.ac.il/poli/code/welcome.htm.

Marshall, Monty \& Keith Jaggers, 2002. 'Polity IV Project: Dataset Users' Manual', Data accessed through http://www.cidcm.umd.edu/inscr/polity/.

Miller, Benjamin, 2001. 'Hot Wars, Cold Peace', in Zeev Maoz \& Azar Gat, eds, War in a Changing World. Ann Arbor, MI: University of Michigan Press (93-142). 
Morrow, James; Randolph Siverson \& Tressa Tabares, 1998. 'The Political Determinants of International Trade: The Major Powers, 1907-1990’, American Political Science Review 92(3): 649-661.

Orme, John, 2004. The Paradox of Peace: Leaders, Decisions, and Conflict Resolution. New York: Palgrave MacMillan.

Owen, John, 1997. Liberal Peace, Liberal War: American Politics and International Security. Ithaca, NY: Cornell University Press.

Owen, John, 2000. 'Pieces of Maximal Peace: Common Identities, Common Enemies', in Arie Kacowicz; Yaacov Bar-Siman-Tov, Ole Elgstrom \& Magnus Jerneck, eds, Stable Peace among Nations. Lanham, MD: Rowman and Littlefield (74-91).

Parry, Clive, 1969-1983. The Consolidated Treaty Series. Dobbs Ferry, NY: Oceana. Pollins, Brian, 1989. 'Does Trade Still Follow the Flag?: A Model of International Diplomacy and Commerce', American Political Science Review 83(2): 465-480. Press-Barnathan, Galia, 2006. 'The Neglected Dimension of Commercial Liberalism: Economic Cooperation and Transition to Peace', Journal of Peace Research 43(3): 261-278.

Putnam, Robert, 1988. 'Diplomacy and Domestic Politics: The Logic of Two-Level Games', International Organization 42(3): 427-460.

Ripsman, Norrin, 2005. 'Two Stages of Transition from a Region of War to a Region of Peace: Realist Transition and Liberal Endurance', International Studies Quarterly 49(4): 669-694.

Rock, Stephen, 1989. Why Peace Breaks out. Chapel Hill: University of North Carolina Press.

Rohn, Peter, 1983. World Treaty Index. Santa Barbara, CA: ABC-Clio Information Services. 
Russett, Bruce, 1993. Grasping the Democratic Peace: Principles for a Post-Cold War World. Ewing, NJ: Princeton University Press, 1993.

Sarkees, Meredith, 2000. 'The Correlates of War Data on War: An Update to 1997', Conflict Management and Peace Science 18(1): 123-144.

Schmitter, Phillipe, 2004. 'The Ambiguous Virtues of Accountability', Journal of Democracy 15(4): 47-60.

Schultz, Kenneth, 2001. Democracy and Coercive Diplomacy. New York: Cambridge University Press.

Senese, Paul \& Stephen Quackenbush, 2003. 'Sowing the Seeds of Conflict: The Effect of Dispute Settlements on Durations of Peace', Journal of Politics 65(3): 696717.

Signorino, Curtis \& Jeffrey Ritter, 1999. 'Tau-b or Not Tau-b: Measuring the Similarity of Foreign Policy Positions', International Studies Quarterly 43(1): 115144.

Singer, David \& Melvin Small, 1973. 'The Diplomatic Importance of States, 1816-1970: An Extension and Refinement of the Indicator', World Politics 25(4): 577-599.

Singer, David; Stuart Bremer \& John Stuckey, 1972. 'Capability Distribution, Uncertainty and Major Power War, 1820-1965', in Bruce Russett, ed., Peace, War and Numbers. Beverly Hills, CA: Sage (19-48).

Small, Melvin \& David Singer, 1982. Resort to Arms: International and Civil War. Beverly Hills, CA: Sage Publications.

Spector, Bertram, 1998. 'Deciding to Negotiate with Villains', Negotiation Journal 14(1): 43-59.

Stam, Allan, 1996. Win, Lose, or Draw: Domestic Politics and the Crucible of War. Ann Arbor, MI: University of Michigan Press. 
Stedman, Stephen, 1997. 'Spoiler Problems in Peace Processes', International Security 22(2): 5-53.

Thompson, William, 2001. 'Identifying Rivals and Rivalries in World Politics', International Studies Quarterly 45(4): 557-586.

Vasquez, John, 1996. 'Understanding Peace: Insights from International Relations Theory and Research', in Thomas Gregor, ed., A Natural History of Peace. Nashville, TN: Vanderbilt University Press (273-295).

Werner, Suzanne,1999. 'The Precarious Nature of the Peace: Resolving the Issues, Enforcing the Settlement, and Renegotiating the Terms', American Journal of Political Science 43(3): 912-934.

Zakaria, Fareed, 1997. 'The Rise of Illiberal Democracy', Foreign Affairs 76(6): 22-43. 
REŞAT BAYER, b. 1977; PhD in Political Science (Pennsylvania State University, 2004); Assistant Professor, Koç University (2005-). Main interests: peace, conflict resolution, democracy and conflict. 